\title{
The Use of Adipose Derived Cells for Skin Nerve Regeneration - Short Review of Experimental Research
}

\author{
Agnes S Klar ${ }^{1,2^{\star}}$, Jakub Zimoch ${ }^{1,2}$ and Thomas Biedermann ${ }^{1,2}$ \\ ${ }^{1}$ University Children's Hospital Zurich, Tissue Biology Research Unit, August Forel Strasse 7, 8008 Zurich, Switzerland \\ ${ }^{2}$ Children's Research Center, University Children's Hospital Zurich, Steinwiesstrasse 75, 8032 Zurich, Switzerland
}

"Corresponding author: Thomas Biedermann, University Children's Hospital Zurich, Tissue Biology Research Unit, August Forel Strasse 7, 8008 Zurich, Switzerland, Tel: +41 44 6348920; E-mail: Thomas.biedermann@kispi.uzh.ch

Received date: January 21, 2017; Accepted date: February 07, 2017; Published date: February 10, 2017

Copyright: (c) 2017 Klar AS, et al. This is an open-access article distributed under the terms of the Creative Commons Attribution License, which permits unrestricted use, distribution, and reproduction in any medium, provided the original author and source are credited.

\begin{abstract}
Burns and other severe skin injuries alter cutaneous perception of pain, temperature, and touch. During skin wound healing, peripheral nerve regeneration can occur from nerve endings of the wound bed, however, a functional recovery after an injury is often not sufficient due to scar formation or impaired wound healing.
\end{abstract}

Keywords Adipose-derived stem cells; Cell-based therapies; Skin wound healing; Stromal vascular fraction; Nerve regeneration; Innervation

\section{Mini Review}

Burns and other severe skin injuries alter cutaneous perception of pain, temperature, and touch. During skin wound healing, peripheral nerve regeneration can occur from nerve endings of the wound bed, however, a functional recovery after an injury is often not sufficient due to scar formation or impaired wound healing.

Experimental studies have demonstrated that Schwann cells derived from nerves can enhance peripheral nerve regeneration [1-4]. Unfortunately, the clinical use of Schwann cells is problematic, as they have only limited in vitro expansion capacity. Therefore, alternatives are needed to promote nerve regeneration.

Recently, adult stromal vascular fraction (SVF) and adipose-derived stem cells (ASCs) emerged as promising cell sources for tissueengineering and regenerative medicine applications due to their relative abundance and accessibility.

In this short review, we present possible applications of SVF and ASCs in the field of skin nerve regeneration as several reports have demonstrated that both SVF $[5,6]$ and ASCs contribute to peripheral nerve regeneration $[7,8]$.

The SVF is a heterogeneous population of various cell types including among many others adipose stromal and hematopoietic stem cells, progenitor cells, endothelial cells, lymphocytes, pericytes, as wells as monocytes and macrophages $[9,10]$. The culture of SVF cells on tissue culture plastic allows the expansion of a subset of adherent, multipotent stromal/stem cells. These cells are termed as adiposederived stem cells (ASCs) and can be maintained in culture.

For nerve repair and regeneration, freshly isolated SVF or cultured ASCs are utilized. Mohammadi et al. demonstrated in implanted fibrin conduits containing SVF a rapid axon recovery, and an increased density and thickness of myelinated fibers [6]. Other strategies have demonstrated the effectiveness of ASCs seeded for instance in silicon conduits and applied in vivo to support functional nerve regeneration [11-14].

Further, another strategy is based on the differentiation of ASCs into Schwann-like cells before using them for nerve repair. Kingham et al. differentiated rat ASCs into Schwann-like cells employing several growth factors mimicking Schwann cell developmental stimuli such as FGF (fibroblast growth factor), PDGF (plateled-derived growth factor), and glial growth factor 2 [4]. Differentiated rat $[4,15,16]$ and also human $[17,18]$ Schwann-like cells expressed in vitro myelin proteins, glial markers, and induced neurite sprouting. Further, coculturing of ASCs with Schwann cells resulted also in differentiation of ASCs into Schwann-like cells [19-21].

In vivo studies have revealed that ASCs-differentiated Schwann-like cells promoted nerve repair and regeneration when delivered in distinct scaffolds, such as fibrin and silicon [22-28]. Tomita et al. demonstrated improved cutaneous nerve regeneration in skin flaps after treatment with ASCs-differentiated Schwann-like cells [29]. Skin innervation was accelerated by pivotal neurotrophic factors and neurotransmitters such as nerve growth factor (NGF) and brain derived neurotrophic factor (BDNF) supporting regrowth of cutaneous axons from the wound bed.

However, there is still no clear evidence whether differentiated Schwann-like cells actively participate in the formation of new myelin sheets or if they only support already present "professional" Schwann cells by releasing various growth factors stimulating nerve regeneration.

To summarize, all aforementioned investigations using human freshly isolated SVF, cultured ASCs or ASCs-differentiated Schwannlike cells have been performed in vitro or in experimental in vivo studies, but no clinical translation was performed so far. However, further preclinical in vivo studies are needed to confirm the safety and effectiveness of human SVF or ASCs prior to their use in future clinical applications.

\section{References}

1. Guenard V, Kleitman N, Morrissey TK, Bunge RP, Aebischer P (1992) Syngeneic Schwann-cells derived from adult nerves seeded in 
Citation: Klar AS, Zimoch J, Biedermann T (2017) The Use of Adipose Derived Cells for Skin Nerve Regeneration - Short Review of Experimental Research. J Tissue Sci Eng 8: 191. doi:10.4172/2157-7552.1000191

Page 2 of 2

semipermeable guidance channels enhance peripheral-nerve regeneration. J Neurosci 12: 3310-3320.

2. Mosahebi A, Simon M, Wiberg M, Terenghi G (2001) A novel use of alginate hydrogel as Schwann cell matrix. Tissue Eng 7: 525-534.

3. Tohill M, Terenghi G (2004) Stem-cell plasticity and therapy for injuries of the peripheral nervous system. Biotechnol Appl Biochem 40: 17-24.

4. Kingham PJ, Kalbermatten DF, Mahay D, Armstrong SJ, Wiberg M, et al. (2007) Adipose-derived stem cells differentiate into a Schwann cell phenotype and promote neurite outgrowth in vitro. Exp Neurol 207: 267-274.

5. You D, Jang MJ, Kim BH, Song G, Lee C, et al. (2015) Comparative study of autologous stromal vascular fraction and adipose-derived stem cells for erectile function recovery in a rat model of cavernous nerve injury. Urology 193: E222-E222.

6. Mohammadi R, Sanaei N, Ahsan S, Rostami H, Abbasipour-Dalivand S, et al. (2014) Repair of nerve defect with chitosan graft supplemented by uncultured characterized stromal vascular fraction in streptozotocin induced diabetic rats. Int J Surg 12: 33-40.

7. Faroni A, Smith RJ, Reid AJ (2014) Adipose derived stem cells and nerve regeneration. Neural Regen Res 9: 1341-1346.

8. Zack-Williams SD, Butler PE, Kalaskar DM (2015) Current progress in use of adipose derived stem cells in peripheral nerve regeneration. World J Stem Cells 7: 51-64.

9. Cawthorn WP, Scheller EL, MacDougald OA (2012) Adipose tissue stem cells meet preadipocyte commitment: going back to the future. J Lipid Res 53: 227-246.

10. Han J, Koh YJ, Moon HR, Ryoo HG, Cho C-H, et al. (2010) Adipose tissue is an extramedullary reservoir for functional hematopoietic stem and progenitor cells. Blood 115: 957-964.

11. Suganuma S, Tada K, Hayashi K, Takeuchi A, Sugimoto N, et al. (2013) Uncultured adipose-derived regenerative cells promote peripheral nerve regeneration. Journal of Orthopaedic Science 18: 145-151.

12. Masgutov RF, Masgutova GA, Zhuravleva MN1, Salafutdinov II, et al. (2016) Human adipose-derived stem cells stimulate neuroregeneration. Clin Exp Med 16: 451-461.

13. Sowa $Y$, Imura T, Numajiri T, Nishino K, Fushiki S (2012) Adiposederived stem cells produce factors enhancing peripheral nerve regeneration: Influence of age and anatomic site of origin. Stem Cells Dev 21: $1852-1862$.

14. Santiago LY, Clavijo-Alvarez J, Brayfield C, Rubin JP, Marra KG (2009) Delivery of adipose-derived precursor cells for peripheral nerve repair. Cell Transplant 18: 145-158.

15. Xu Y, Liu L, Li Y, Zhou C, Xiong F, et al. (2008) Myelin-forming ability of Schwann cell-like cells induced from rat adipose-derived stem cells in vitro. Brain Res 1239: 49-55.

16. de Luca AC, Faroni A, Downes S, Terenghi G (2016) Differentiated adipose-derived stem cells act synergistically with RGD-modified surfaces to improve neurite outgrowth in a co-culture model. J Tissue Eng Regen Med 10: 647-655.

17. Tomita K, Madura T, Sakai Y, Yano K, Terenghi G, et al. (2013) Glial differentiation of human adipose-derived stem cells: Implications for cellbased transplantation therapy. Neuroscience 236: 55-65.

18. Kingham PJ, Kolar MK, Novikova LN, Novikov LN, Wiberg M (2014) Stimulating the neurotrophic and angiogenic properties of human adipose-derived stem cells enhances nerve repair. Stem Cells Dev 23: 741-754.

19. Radtke C, Schmitz B, Spies M, Kocsis JD, Vogt PM (2009) Peripheral glial cell differentiation from neurospheres derived from adipose mesenchymal stem cells. Int J Dev Neurosci 27: 817-823.

20. Razavi S, Ahmadi N, Kazemi M, Mardani M, Esfandiari E (2012) Efficient transdifferentiation of human adipose-derived stem cells into Schwannlike cells: A promise for treatment of demyelinating diseases. Adv Biomed Res 1:12.

21. Hsueh YY, Chang YJ, Huang TC, Fan SC, Wang DH, et al. (2014) Functional recoveries of sciatic nerve regeneration by combining chitosan-coated conduit and neurosphere cells induced from adiposederived stem cells. Biomaterials 35: 2234-2244.

22. di Summa PG, Kingham PJ, Raffoul W, Wiberg M, Terenghi G, et al. (2010) Adipose-derived stem cells enhance peripheral nerve regeneration. J Plast Reconstr Aesthet Surg 63: 1544-1552.

23. di Summa PG, Kalbermatten DF, Pralong E, Raffoul W, Kingham PJ, et al. (2011) Long-term in vivo regeneration of peripheral nerves through bioengineered nerve grafts. Neuroscience 181: 278-291.

24. Orbay H, Uysal AC, Hyakusoku H, Mizuno H (2012) Differentiated and undifferentiated adipose-derived stem cells improve function in rats with peripheral nerve gaps. J Plast Reconstr Aesthet Surg 65: 657-664.

25. Carriel V, Garrido-Gomez J, Hernandez-Cortes P, Garzon I, GarciaGarcia S, et al. (2013)Combination of fibrin-agarose hydrogels and adipose-derived mesenchymal stem cells for peripheral nerve regeneration. J Neural Eng 10: 026022.

26. Reichenberger MA, Mueller W, Hartmann J, Diehm Y, Lass U, et al. (2015) ADSCs in a fibrin matrix enhance nerve regeneration after epineural suturing in a rat model. Microsurgery 36: 491-500.

27. Lasso JM, Cano RP, Castro Y, Arenas L, Garcia J, et al. (2015) Xenotransplantation of human adipose-derived stem cells in the regeneration of a rabbit peripheral nerve. J Plast Reconstr Aes 68: E189E197.

28. Kappos EA, Engels PE, Tremp M, Schwabedissen MMZ, di Summa P, et al. (2015) Peripheral nerve repair: Multimodal comparison of the longterm regenerative potential of adipose tissue-derived cells in a biodegradable conduit. Stem Cells Dev 24: 2127-2141.

29. Tomita K, Nishibayashi A, Yano K, Hosokawa K (2013) Differentiated adipose-derived stem cells promote reinnervation of rat skin flaps. Plast Reconstr Surg Glob Open 1: e22. 